\title{
Epidemiology of occupational injuries among insured workers in Saudi Arabia between 2004 and 2016
}

\author{
Mohsin Abbas $^{1,2}$, Rashid Saeed ${ }^{1}$, and Zaki-ul-Zaman Asam ${ }^{1}$ \\ ${ }^{1}$ University of Gujrat Faculty of Sciences, Department of Environmental Sciences, Gujrat, Pakistan \\ ${ }^{2}$ King Abdul-Aziz University, Department of Environmental Sciences, Jeddah, Saudi Arabia
}

[Received in December 2019; Similarity Check in December 2019; Accepted in March 2021]

This is a retrospective analysis of annual reports on occupational injuries issued by the national social insurance agency of the Kingdom of Saudi Arabia (KSA) for the years 2004 through 2016. For each criterion we calculated an index based on the equation $N_{Y} / N_{\text {ref }}$ x100, where $N_{Y}$ is the number of occupational injuries by a specific criterion in a specific year $Y$, and $N_{\text {ref }}$ is the number of injuries in the corresponding criterion in the reference year, i.e. 2004. We also calculated the number of injuries to number of workers ratio $\left(N / N_{w}\right)$ for different occupations and economic sectors to get a clearer idea of the injury trends per worker. In terms of occupational injury rates (with respect to 2004), we observed increases in construction, financing \& real estate (economic sectors), among engineers and technicians (occupations), in infections and secondary contusions (injury type), for upper and lower limbs (affected body parts), over falls and "other" causes. Most injuries occurred on Fridays, which is a weekend day in Saudi Arabia. We also observed increased recovery without disability (injury status). However, if we look at the number of occupational injuries per worker, we can see a decreasing trend over time for all occupations and economic sectors, most likely thanks to improved labour law and safety at work practices for insured workers. Our findings are similar to reports from other Persian Gulf countries and reflect current labour health and safety issues in the area.

KEY WORDS: construction workers; contusions; engineers; General Organization for Social Insurance; infections; labour; Persian Gulf countries; technicians

Around the world work-related diseases and occupational injuries have been estimated to cause 2.3 million deaths $(2$ and 0.3 , respectively) every year with an economic cost between 1.8 and $6.0 \%$ (average $4 \%$ ) of gross domestic product (1). Adding absenteeism and productivity decreases (2) to the unfortunate score gives an even better idea about the significance of occupational injury burden on the society $(3,4)$. In industrial countries, however, improved prevention and structural modifications have brought down this number of occupational injuries (5). The road towards this goal starts with the collection and analysis of occupational injury data $(4,6,7)$. Arab countries seem to lag behind in this respect, most likely due to lack of awareness, regional data $(7,8)$, and analysis.

The Kingdom of Saudi Arabia (KSA) is a rapidly industrialising country with the ambition to minimise dependence on oil reserves in the future. Saudi labour market is flourishing with many businesses and a large workforce operating heavy machinery and equipment. Health and safety of workers are regulated by a legal framework and a number of governmental and nongovernmental occupational health and safety organisations

Corresponding author: Mohsin Abbas, University of Gujrat Faculty of Sciences, Department of Environmental Sciences, Hafiz Hayat Campus, Jabalpur Road, Gujrat, Pakistan, E-mail: mohsinabbas34@yahoo.com; mohsin.abbas@uog.edu.pk
(9), including the General Organization for Social Insurance (GOSI), a government agency for the implementation of social insurance laws with a board of directors who represent Saudi ministries of labour, finance, and health, employers, and qualified workers. GOSI collects fixed taxes to cover insurance for injured workers and their family members. Employers pay $2 \%$ of worker salaries, which can be raised to $4 \%$ if the employers do not meet occupational health and safety requirements set by GOSI.

According to Hämäläinen et al. (10), these efforts had produced a drop in occupational accidents in the KSA by 2003. The aim of our study was to see current trends based on a retrospective analysis of occupational injury data provided by GOSI for the years 2004 through 2016. To the best of our knowledge, this is the first comprehensive epidemiological study of occupational injuries on the national level.

\section{DATA AND METHODOLOGY}

\section{Data source and study population}

We used open data on occupational injuries from annual statistical reports issued by GOSI (https://www.gosi.gov. sa) for the years 2004 through 2016 and extracted them into Microsoft Excel datasheets according to the following 
criteria: injury recovery, cause of injuries, economic sector, occupation, injured body parts, nature of injury, and weekday. Records for the years between 2012 and 2016, however, lack info on types of injuries, injured body parts, and weekday.

Between 2004 and 2016, hundreds of thousands of registered establishments had employed from less than three million insured workers in 2004 to over ten million in 2016, most of whom were blue collar expats.

\section{Analysis}

To investigate epidemiological trends of occupational injuries/accidents in the KSA we relied on the index method used before for Turkey, Pakistan, and Saudi Arabia (11-13). The index for the year $Y$ was calculated with respect to reference year using the following equation:

$$
\left(N_{Y} / N_{r e f}\right) \times 100 \text {, }
$$

where $N_{Y}$ is the total number of occupational injuries in the year $Y$, and $N_{\text {ref }}$ is the number of injuries in the reference year. Indices above 100 indicate increase. For example, index 125 means a $25 \%$ increase in the total number of injuries compared to the reference year, while index 50 means a $50 \%$ drop.

To see the trend per insured worker in a specific year, we also calculated injury-to-worker ratio $\left(N_{i} / N_{w}\right)$, where $N_{i}$ stands for the total number of all or specific occupational injuries divided by the number of insured workers in a particular year.

We used the simple linear regression model to calculate the slope values of subcategories by considering number of years $(x)$ as independent variable and percentage of occupational injuries $(y)$ as dependent variable. Assuming a linear trend, positive value of slope indicates upward trend through years, while a negative slope value indicates a downward trend. The equation for the slope of the regression line was

$$
b=\frac{\sum(x-\bar{x})(y-\bar{y})}{\sum(x-\bar{x})^{2}}
$$

\section{RESULTS}

\section{Total occupational injuries and deaths}

Table 1 shows the number of establishments, insured workers, Saudi workers (SW), foreign workers (FW), occupational injuries (total and their distribution between SW and FW), and occupational deaths in the KSA between 2004 and 2016. A total of 6562 occupational deaths was recorded over the studied period, averaging 505 a year. Quite expectedly, occupational injuries were far more common among foreign workers than Saudi nationals (93.5\% vs $6.5 \%$, respectively) (Table 1), whose number increased over $300 \%$ by 2016, but the annual number of injuries dropped by more than $40 \%$ by that time (Figure $1)$.

\section{Distribution of occupational injuries by economic sectors}

Over the studied period, the highest percentage of occupational injuries was recorded in construction (46.5\%), followed by trade $(23.8 \%)$ and manufacturing (17.9\%). The share of occupational injuries in construction, financing \& real estate, and mining \& quarry increased over the years, while it decreased in trade, manufacturing, and social services. However, the injury-to-worker ratio $\left(N_{i} / N_{w}\right)$ decreased for all these economic sectors over the same period, as the number of injuries for each sector either

Table 1 The distribution of establishments, insured workers, occupational deaths, and injuries in Saudi Arabia between 2004 and 2016

\begin{tabular}{ccccccccc}
\hline Year & TE & TIW & SW & FW & TOI & OISW & OIFW & TOD \\
\hline 2004 & 105462 & 2793757 & 571806 & 2221951 & 93521 & 6470 & 87051 & 320 \\
\hline 2005 & 121554 & 3040134 & 654530 & 2385604 & 102259 & 7543 & 94716 & 493 \\
\hline 2006 & 138002 & 3359566 & 723388 & 2636178 & 90853 & 7156 & 83697 & 437 \\
\hline 2007 & 163764 & 3749575 & 753890 & 2995685 & 91822 & 7129 & 84693 & 506 \\
\hline 2008 & 192685 & 4031146 & 765224 & 3265922 & 93285 & 6548 & 86737 & 646 \\
\hline 2009 & 218363 & 4390447 & 790332 & 3600115 & 86211 & 5579 & 80632 & 587 \\
\hline 2010 & 242561 & 4744134 & 838291 & 3905843 & 75487 & 4641 & 70846 & 507 \\
\hline 2011 & 274034 & 5397485 & 1014889 & 4382596 & 75825 & 4357 & 71468 & 557 \\
\hline 2012 & 335773 & 6985687 & 1279952 & 5705735 & 65656 & 3659 & 61997 & 351 \\
\hline 2013 & 419485 & 9089891 & 1608238 & 7481653 & 52467 & 3005 & 49462 & 285 \\
\hline 2014 & 396512 & 9386250 & 1565453 & 7820797 & 69241 & 3732 & 65509 & 856 \\
\hline 2015 & 420941 & 10122477 & 1892812 & 8229665 & 67087 & 3082 & 64005 & 495 \\
\hline 2016 & 453389 & 10489211 & 1875967 & 8613244 & 53404 & 2766 & 50638 & 522
\end{tabular}

TE - total establishments; TIW - total insured workers; SW - resident Saudi workers; FW - foreign workers; TOI - total occupational injuries; OISW - occupational injuries to resident Saudi workers; OIFW - occupational injuries to foreign workers; TOD - total occupational deaths 
decreased or increased at a slower rate than the number of insured workers in the corresponding sector (Table 2).

\section{Distribution of occupational injuries by occupations}

The highest percentage of occupational injuries was recorded among service workers $(45.2 \%)$, followed by engineers $(43.9 \%)$ and technicians $(4.5 \%)$. Over the years, the share of injuries increased among engineers, technicians, and industrial, chemical \& food workers, while it decreased among service workers and clerical \& related workers (Table 3). As with economic sectors, the injury-to-worker ratio decreased for all occupations.

\section{Distribution of occupational injuries by type}

The most common types of occupational injuries between 2004 and 2011 were secondary contusions $(33.1 \%)$, cuts and punctures $(23.5 \%)$, twists and stretches $(10.8 \%)$, fractures and crushes $(7.9 \%)$, infections $(4.3 \%)$, and unspecified occupational injuries (16.0\%). Figure 4 shows occupational injury indices among insured workers by types of injuries. When we take 2004 as a reference year, the indices of all types of occupational injuries increased by 2011, save for twists \& stretches and unspecified injuries (Table 4).

\section{Occupational injuries by affected body parts}

Between 2004 and 2011, the distribution of occupational injuries by body part was as follows: non-classifiable (24.8\%), upper extremities $(22.4 \%)$, lower extremities (20.6\%), head (14.4\%), and trunk (12.8\%). Table 5 shows that the percentage of occupational injuries of upper and lower extremities increased over that period, but none of the indices showed a linear trend in either direction (Figure $5)$.

\section{Occupational injuries by cause}

The most common causes of occupational injuries were hits $(35.8 \%)$, falls $(23.5 \%)$, abrasions/frictions (16.5\%), allergic body reactions ( $9.8 \%$ ), and other causes (fire, hot liquid, drowning, suffocation, or poisoning) $(6.0 \%)$. The index of the last, unspecified causes reached $1371 \%$ at the end of 2016, while other indices dropped (Figure 6). Similarly, injuries from falls and other causes showed a net percentage increase (Table 6).

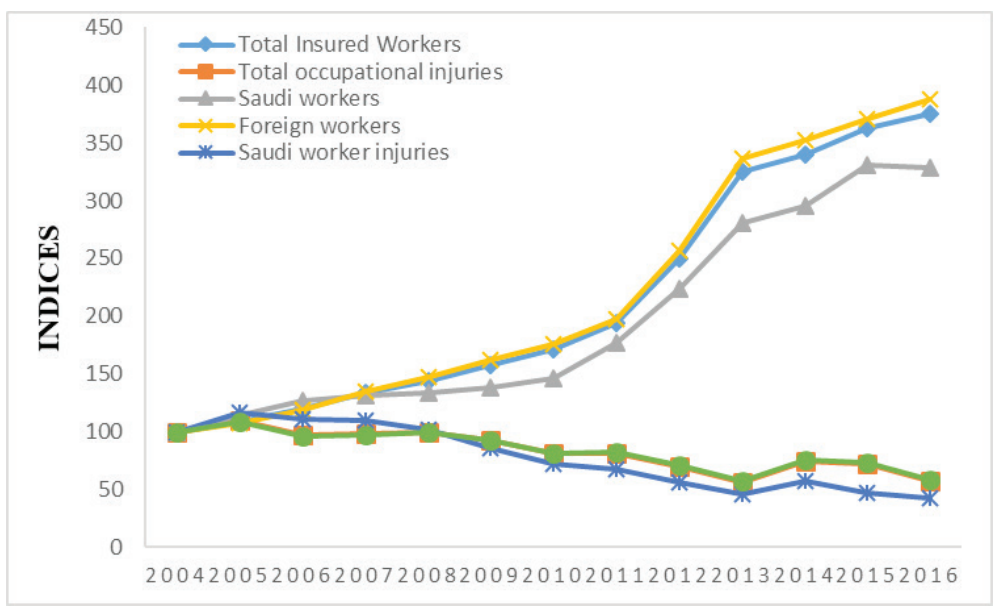

Figure 1 Trends in worker and occupational injury indices in Saudi Arabia between 2004 and 2016

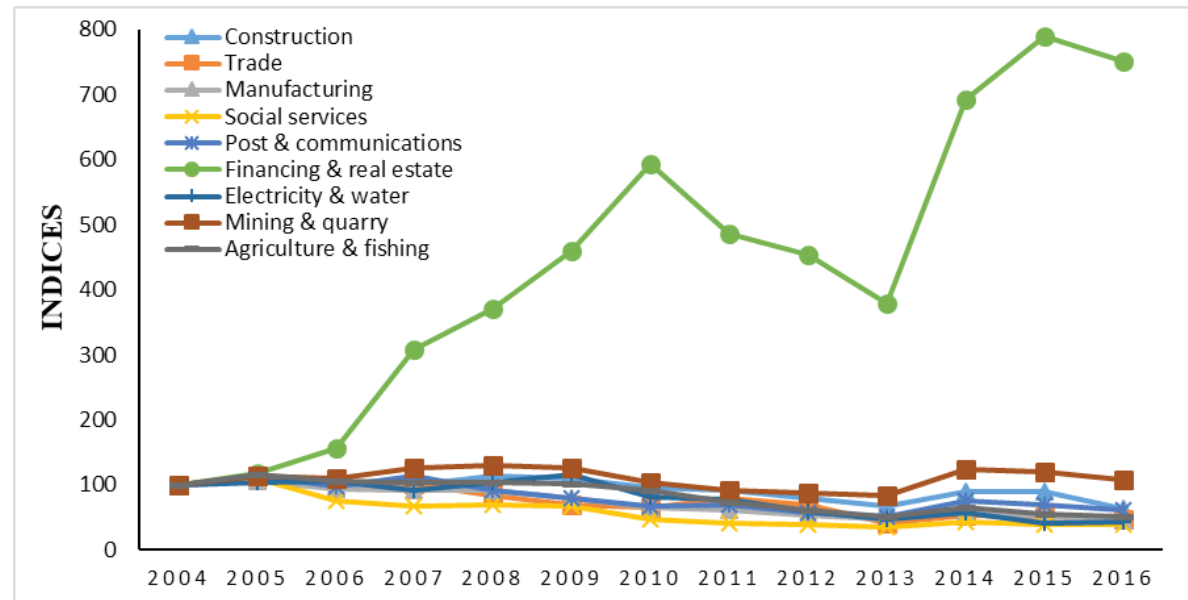

Figure 2 Trends in occupational injuries by economic sectors in Saudi Arabia between 2004 and 2016 


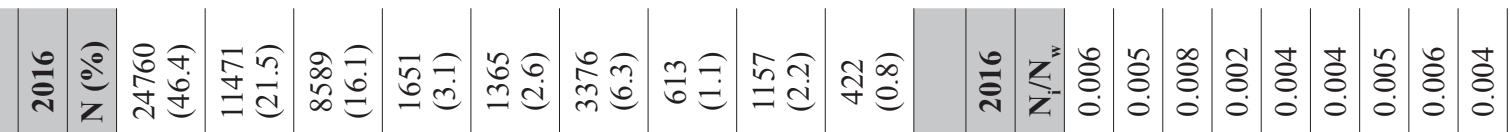

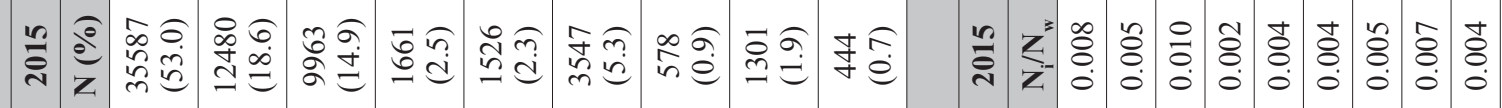

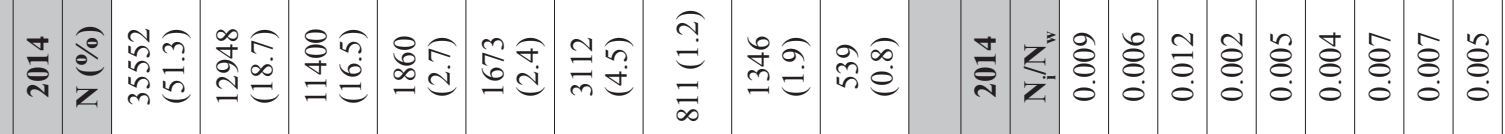

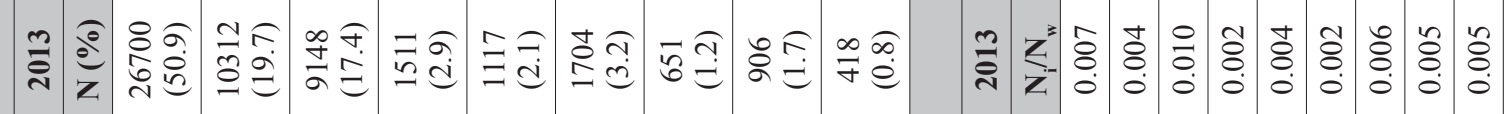

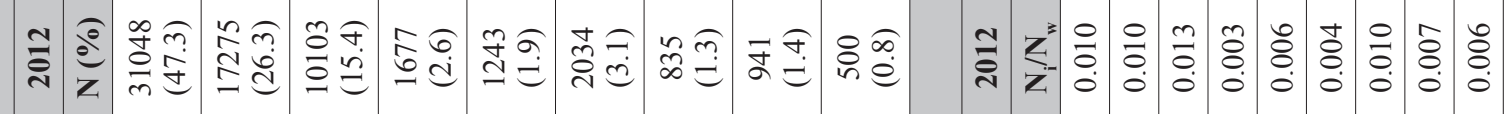

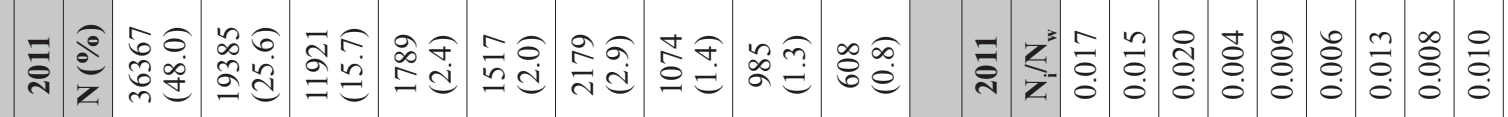

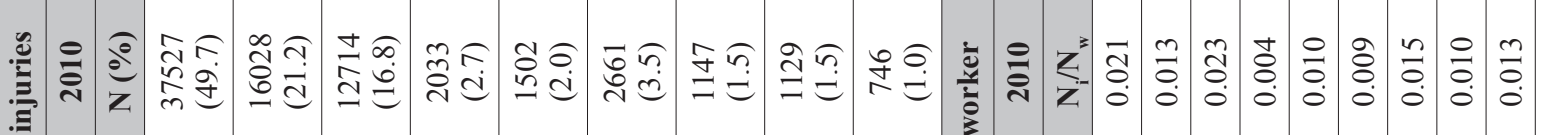

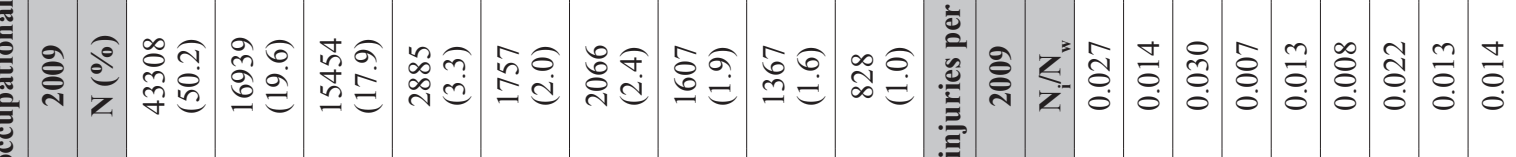

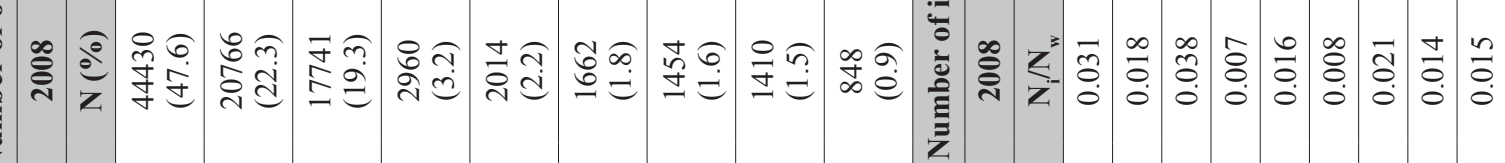

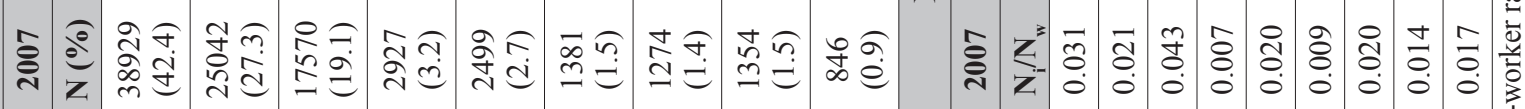

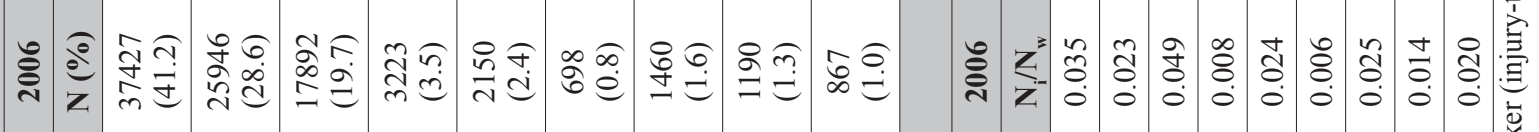

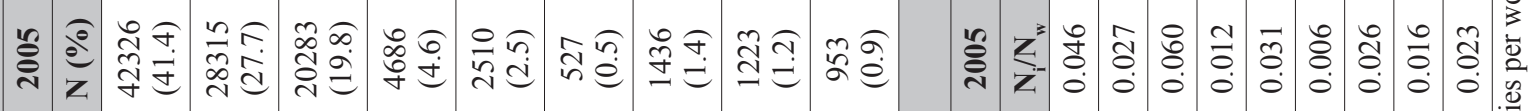

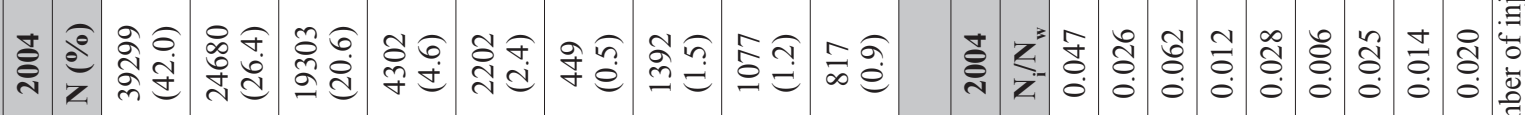
讨

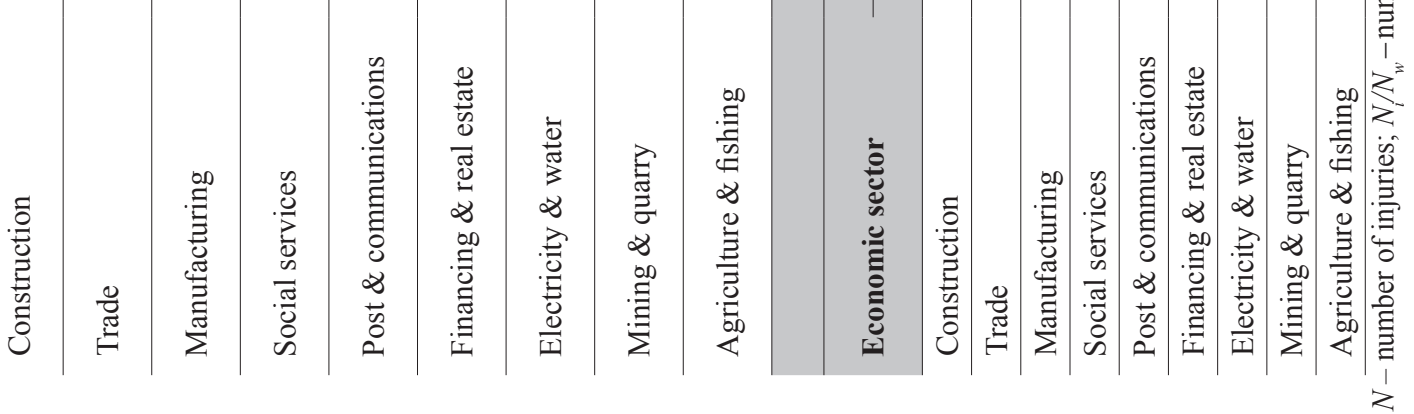




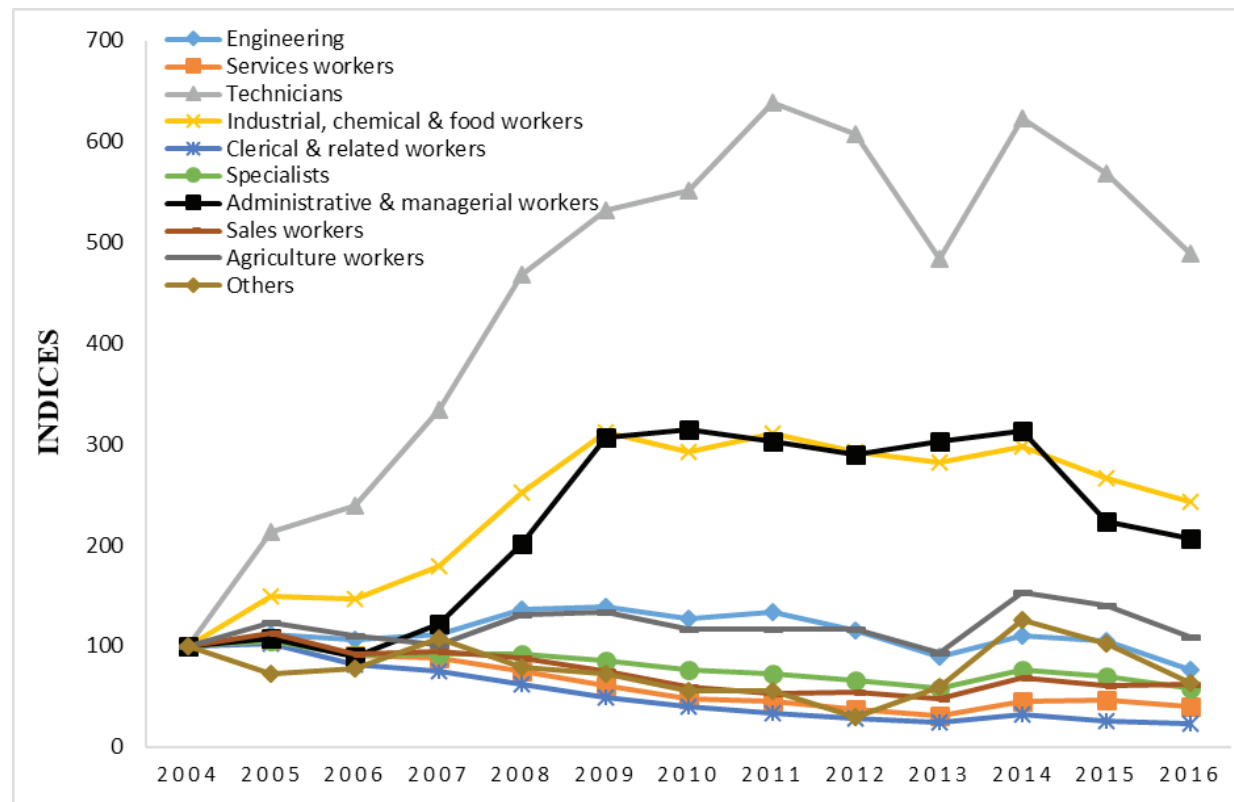

Figure 3 Trends in occupational injuries by occupations in Saudi Arabia between 2004 and 2016

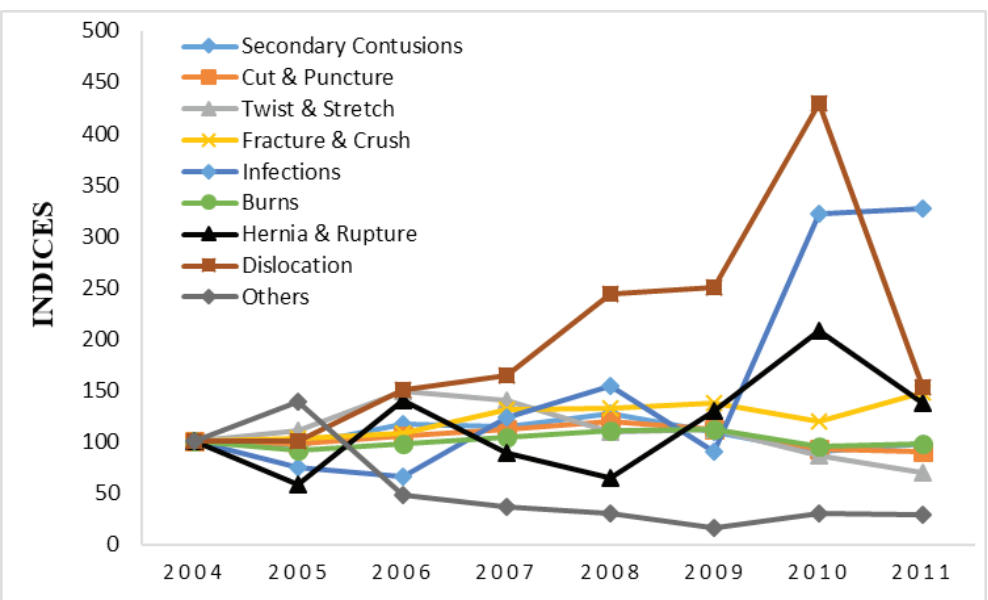

Figure 4 Trends in occupational injuries by type in Saudi Arabia between 2004 and 2011

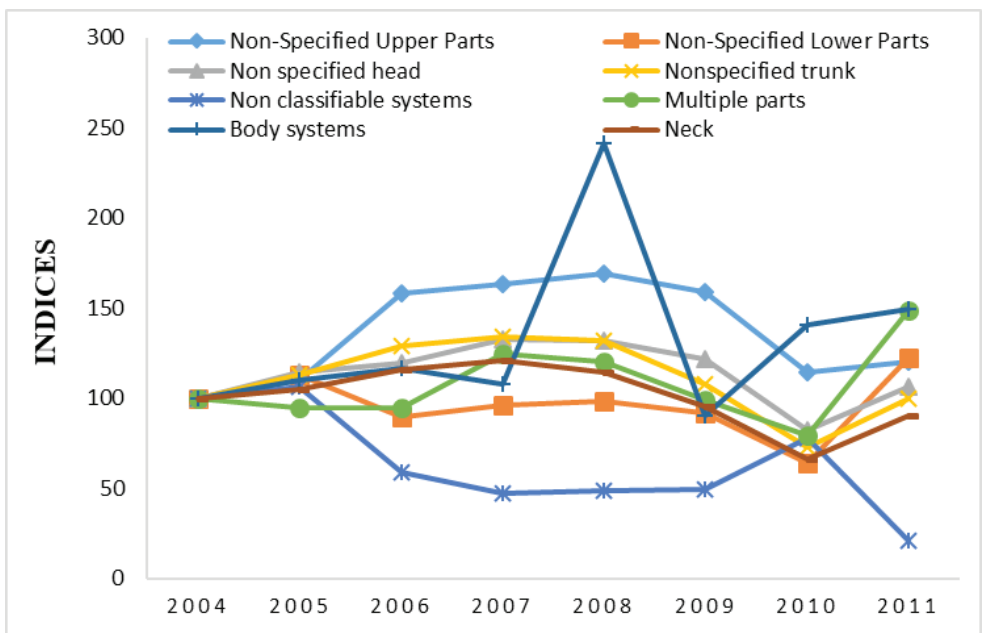

Figure 5 Trends in occupational injuries by injured body part in Saudi Arabia between 2004 and 2011 


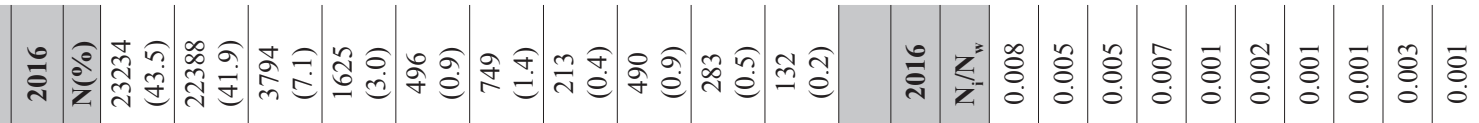

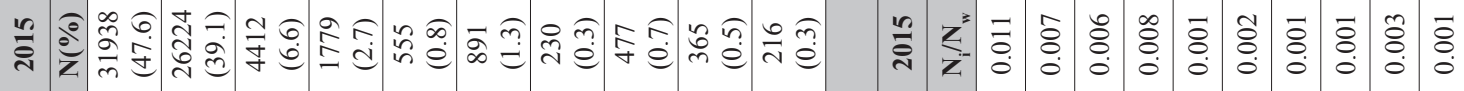

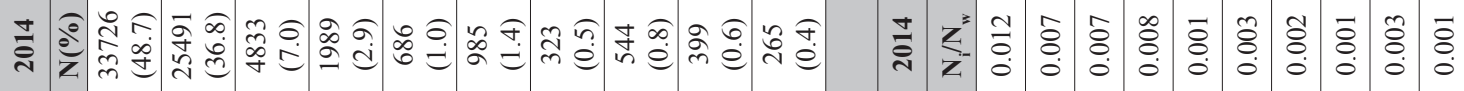

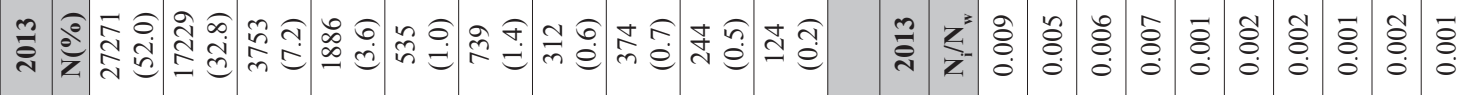

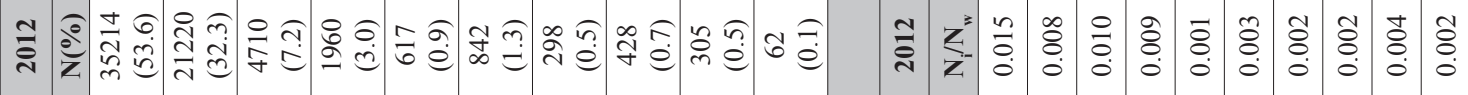

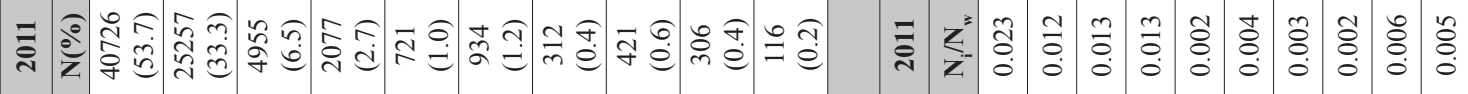

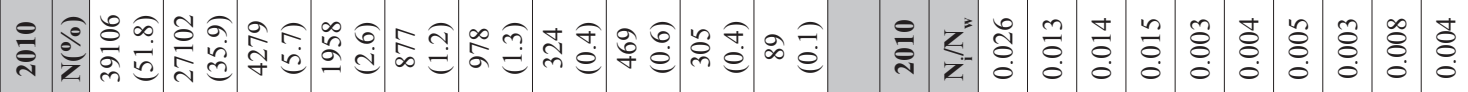

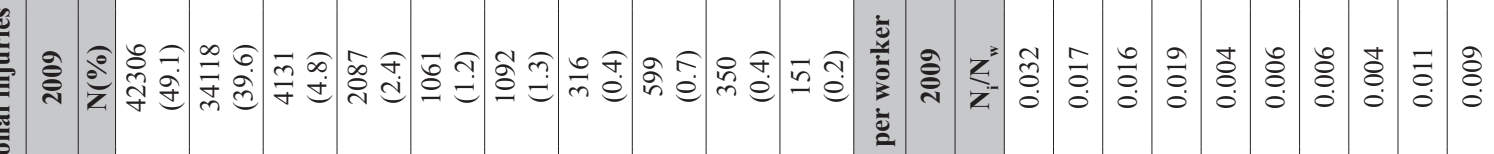

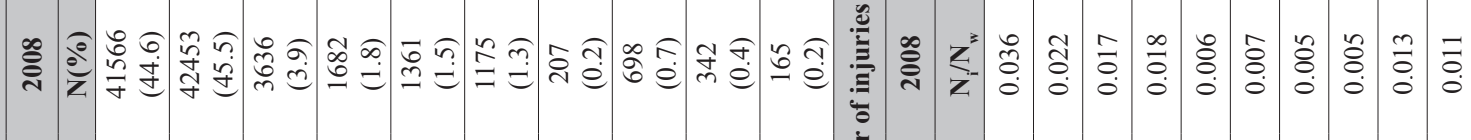

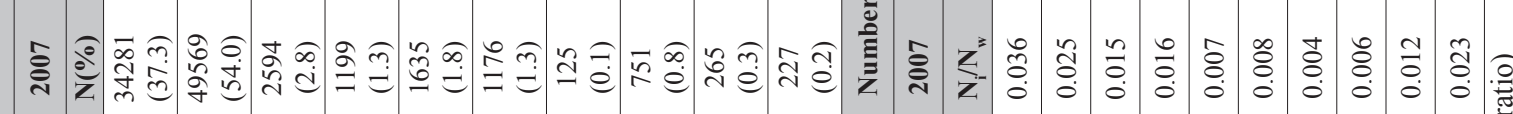

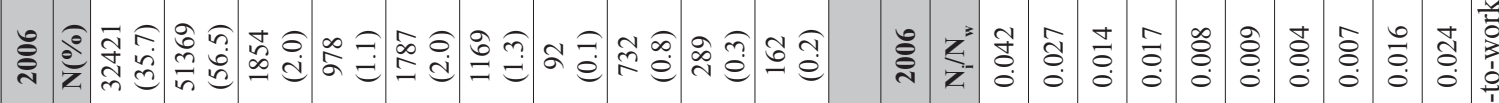

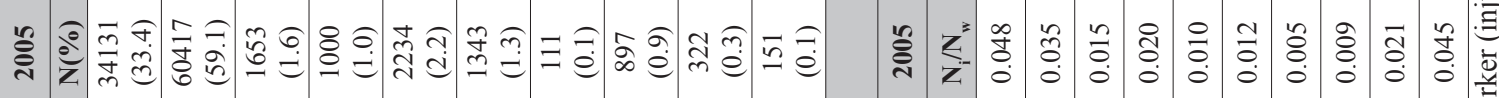

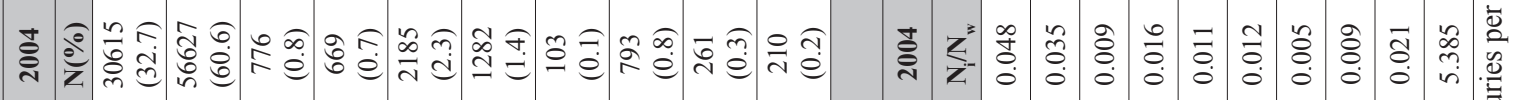

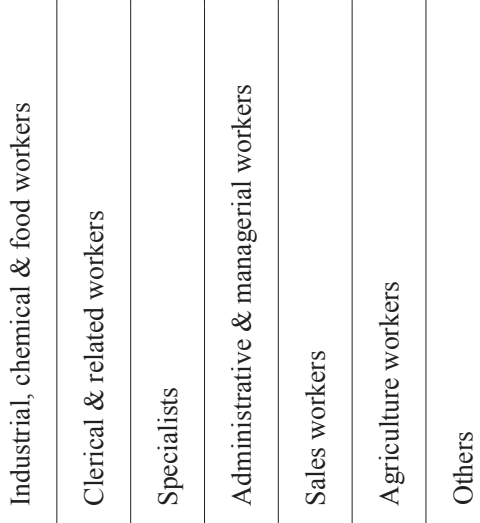
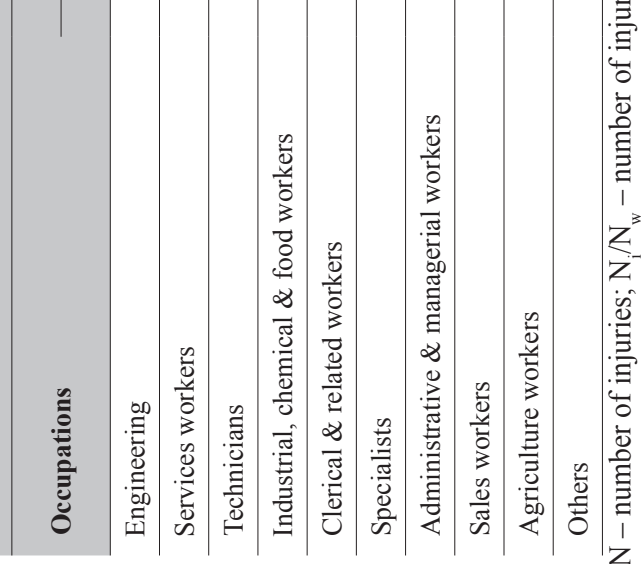
Table 4 Distribution of occupational injuries by type in Saudi Arabia between 2004 and 2011, expressed in percentages

\begin{tabular}{lccccccccc}
\hline $\begin{array}{l}\text { Type of occupational } \\
\text { injuries }\end{array}$ & $\mathbf{2 0 0 4}$ & $\mathbf{2 0 0 5}$ & $\mathbf{2 0 0 6}$ & $\mathbf{2 0 0 7}$ & $\mathbf{2 0 0 8}$ & $\mathbf{2 0 0 9}$ & $\mathbf{2 0 1 0}$ & $\mathbf{2 0 1 1}$ & Slope \\
\hline Secondary contusions & 29.1 & 25.9 & 35.5 & 35.1 & 38.3 & 37.3 & 31.3 & 34.0 & $\mathbf{0 . 8}$ \\
\hline Cut \& puncture & 21.3 & 19.0 & 23.3 & 24.9 & 26.3 & 27.7 & 23.5 & 22.9 & $\mathbf{0 . 6}$ \\
\hline Twist \& stretch & 9.3 & 9.4 & 14.3 & 13.6 & 10.5 & 12.1 & 9.5 & 7.6 & $\mathbf{- 0 . 2}$ \\
\hline Fracture \& crush & 6.0 & 5.7 & 6.8 & 8.3 & 8.3 & 9.6 & 8.6 & 10.6 & $\mathbf{0 . 7}$ \\
\hline Infections & 2.6 & 1.8 & 1.8 & 3.3 & 4.1 & 2.7 & 9.9 & 10.0 & $\mathbf{1 . 1}$ \\
\hline Burns & 1.8 & 1.5 & 1.8 & 2.0 & 2.1 & 2.4 & 2.1 & 2.1 & $\mathbf{0 . 1}$ \\
\hline Hernia \& rupture & 1.5 & 0.8 & 2.3 & 1.4 & 1.0 & 2.3 & 3.8 & 2.5 & $\mathbf{0 . 3}$ \\
\hline Dislocation & 0.2 & 0.2 & 0.4 & 0.4 & 0.6 & 0.7 & 1.2 & 0.4 & $\mathbf{0 . 1}$ \\
\hline Unspecified & 28.2 & 35.7 & 13.9 & 10.8 & 8.7 & 5.2 & 10.1 & 9.9 & $\mathbf{- 3 . 4}$ \\
\hline Total & 100.0 & 100.0 & 100.0 & 100.0 & 100.0 & 100.0 & 100.0 & 100.0 & $\mathbf{0 . 8}$ \\
\hline
\end{tabular}

Table 5 Distribution of occupational injuries by injured body parts in Saudi Arabia between 2004 and 2011, expressed in percentages

\begin{tabular}{lccccccccc}
\hline Injured body parts & $\mathbf{2 0 0 4}$ & $\mathbf{2 0 0 5}$ & $\mathbf{2 0 0 6}$ & $\mathbf{2 0 0 7}$ & $\mathbf{2 0 0 8}$ & $\mathbf{2 0 0 9}$ & $\mathbf{2 0 1 0}$ & $\mathbf{2 0 1 1}$ & Slope \\
\hline Upper limbs & 15.5 & 15.6 & 25.3 & 25.8 & 26.3 & 26.7 & 21.9 & 23.0 & $\mathbf{1 . 1}$ \\
\hline Lower limbs & 20.2 & 20.8 & 18.6 & 19.8 & 19.9 & 20.1 & 16.0 & 30.5 & $\mathbf{0 . 6}$ \\
\hline Head & 12.0 & 12.6 & 14.8 & 16.2 & 15.9 & 15.9 & 12.3 & 15.8 & $\mathbf{0 . 3}$ \\
\hline Trunk & 10.9 & 11.3 & 14.5 & 14.9 & 14.5 & 12.8 & 9.8 & 13.4 & $\mathbf{0 . 1}$ \\
\hline Non-classifiable & 37.0 & 35.9 & 22.4 & 17.8 & 18.0 & 19.9 & 35.6 & 9.6 & $\mathbf{- 2 . 4}$ \\
\hline Multiple parts & 3.7 & 3.2 & 3.6 & 4.7 & 4.4 & 4.0 & 3.6 & 6.7 & $\mathbf{0 . 3}$ \\
\hline Body systems & 0.3 & 0.3 & 0.3 & 0.3 & 0.6 & 0.3 & 0.4 & 0.5 & $\mathbf{0 . 0}$ \\
\hline Neck & 0.4 & 0.4 & 0.5 & 0.5 & 0.4 & 0.4 & 0.3 & 0.4 & $\mathbf{0 . 0}$ \\
\hline Total & 100.0 & 100.0 & 100.0 & 100.0 & 100.0 & 100.0 & 100.0 & 100.0 & \\
\hline
\end{tabular}

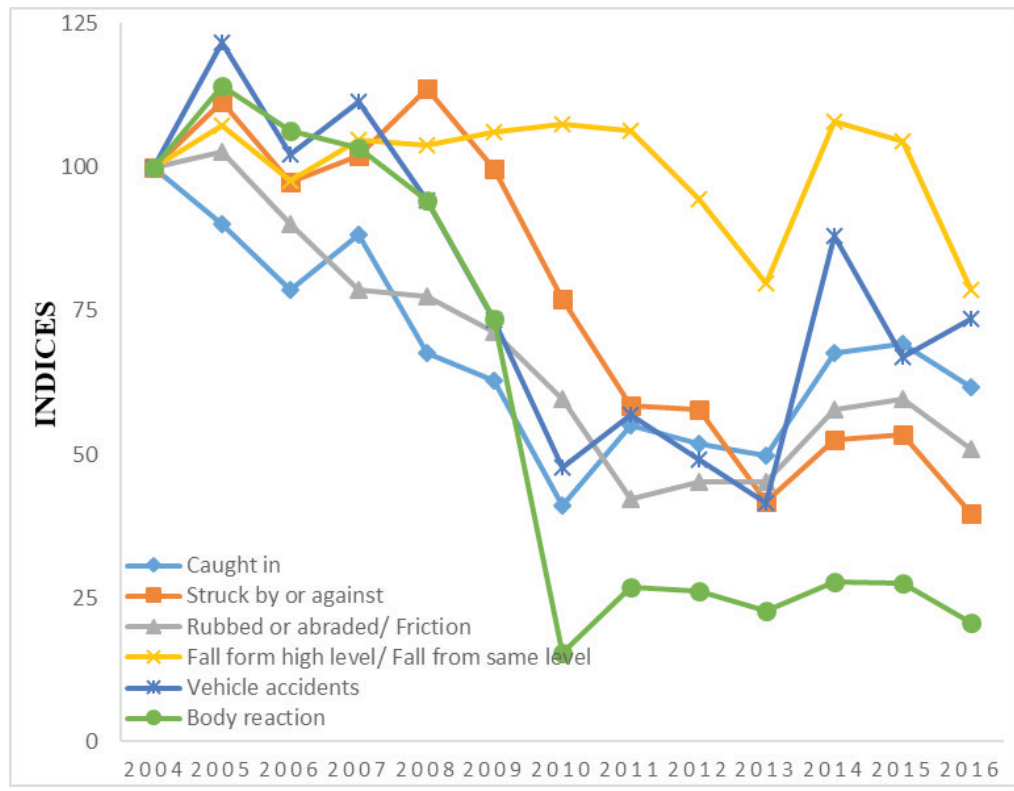

Figure 6 Trends in occupational injuries by causes in Saudi Arabia between 2004 and 2016 

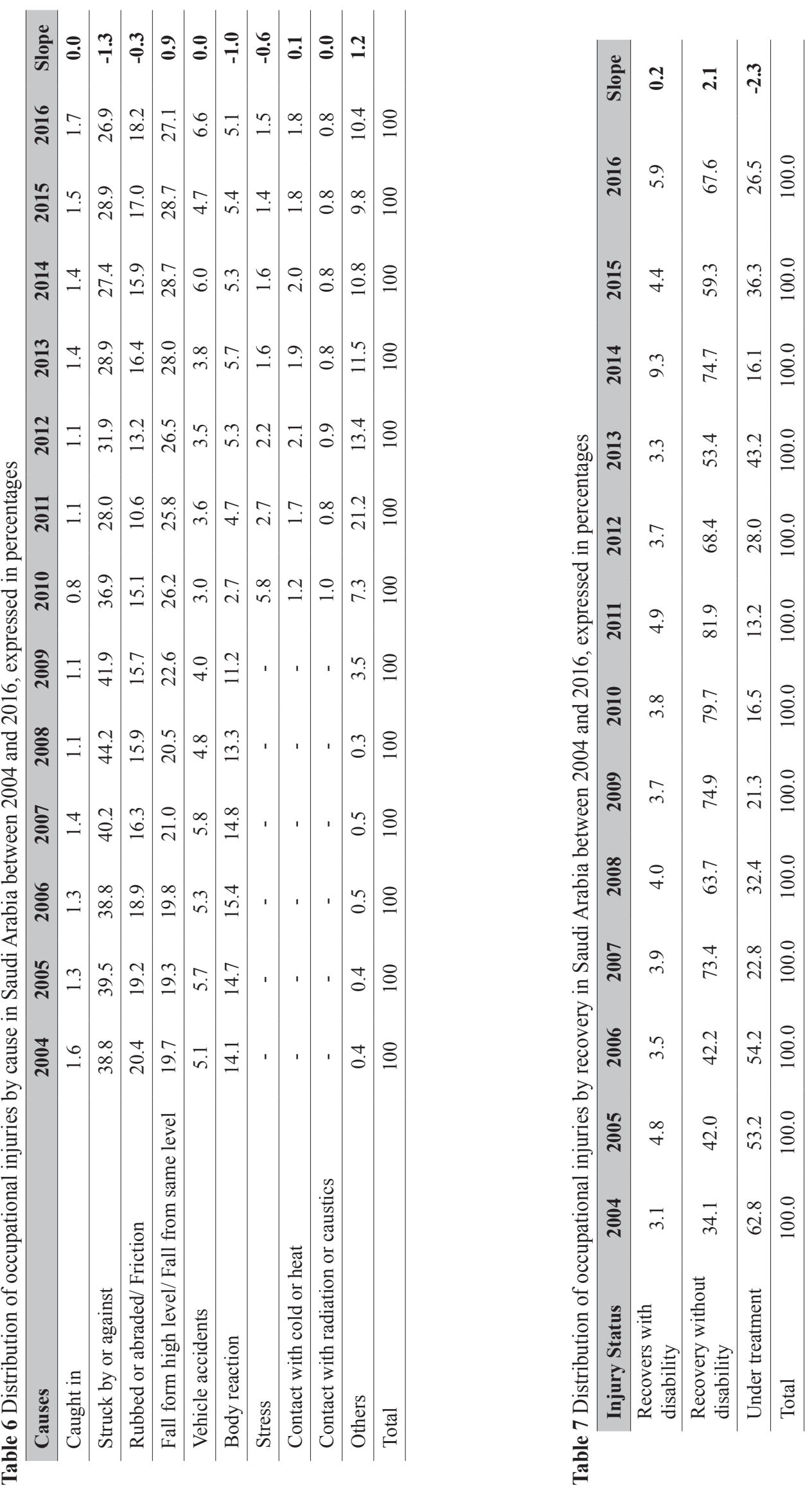


\section{Occupational injuries by recovery status}

By recovery, most injuries ended in full recovery (recovery without disability, RWOD, 61.2\%), followed by those still under treatment (UT, $33.7 \%$ ), those ending in a disability (recovery with disability, RWD, $4.4 \%$ ), and death (OD, $0.6 \%$ ). The indices of RWOD and RWD increased by the end of 2016, while those of UT decreased (Figure 7). The net percentage of the last decreased over the years, while that of RWOD increased (Table 7).

\section{Occupational injury distribution by day of the week}

Between 2004 and 2011, Mondays saw the highest percentage of occupational injuries $(16.6 \%)$ and Saturdays the lowest $(8.9 \%)$. Indices show the highest rise in Friday injuries $(265.3 \%)$ by the end of 2011, and the greatest drop was observed on Saturdays (24.4\%) (Figure 8). Fridays also showed the highest net percentage increase in occupational injuries and Saturdays the greatest percentage fall (Table 8).

\section{DISCUSSION}

This study confirmed a relative drop in occupational injuries per worker from 2004 to 2016, already reported by Hämäläinen et al. (10). The injury-to-worker ratio dropped in all sectors, as the number of injuries either decreased or increased at a much slower rate than the number of insured workers. This downward trend may be owed to improvements in GOSI cooperation with other local agencies and stricter enforcement of labour laws and occupational health and safety policies as the number of insured workers grew in the KSA. We observed a significant difference in the number occupational injuries between Saudi residents and foreign workforce, and these findings are similar to earlier findings in the KSA and the United Arab Emirates (UAE) (11, 12).

This study has also confirmed that construction is the leading sector in terms of occupational injuries. This issue with many construction companies in the KSA has already been addressed by Al Haadir et al. (13), who identified the following factors as critical for the implementation of an operational safety programme among Saudi construction companies: management support, clear and reasonable objectives, personal attitude, teamwork, effective enforcement, safety training, and close supervision.

As for injury incidence by occupation, it was the highest among engineering, technicians, and industrial, chemical $\&$ food workers as reported elsewhere (11) and can be associated with the nature of manual work. However, the increasing injury trend among workforce reported by GOSI as "administrative workers" may raise a few questions about

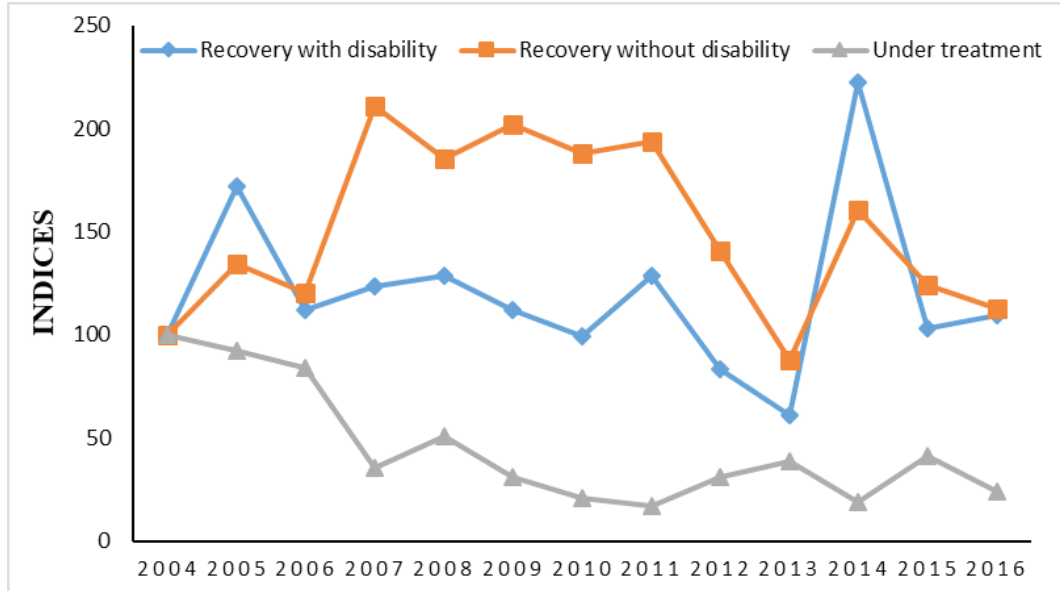

Figure 7 Trends in occupational injuries by recovery in Saudi Arabia between 2004 and 2016

Table 8 Distribution of occupational injuries by day of the week in Saudi Arabia between 2004 and 2011, expressed in percentages

\begin{tabular}{lccccccccc} 
Day & $\mathbf{2 0 0 4}$ & $\mathbf{2 0 0 5}$ & $\mathbf{2 0 0 6}$ & $\mathbf{2 0 0 7}$ & $\mathbf{2 0 0 8}$ & $\mathbf{2 0 0 9}$ & $\mathbf{2 0 1 0}$ & $\mathbf{2 0 1 1}$ & Slope \\
\hline Saturday & 18.6 & 16.3 & 8.0 & 8.4 & 4.0 & 3.7 & 3.9 & 5.6 & $\mathbf{- 2 . 0}$ \\
\hline Sunday & 16.5 & 16.8 & 17.8 & 17.6 & 18.5 & 18.0 & 18.6 & 18.0 & $\mathbf{0 . 2}$ \\
\hline Monday & 16.4 & 16.6 & 16.3 & 16.6 & 16.8 & 16.5 & 16.7 & 16.6 & $\mathbf{0 . 0}$ \\
\hline Tuesday & 16.1 & 15.8 & 16.0 & 16.3 & 16.2 & 16.6 & 16.4 & 16.6 & $\mathbf{0 . 1}$ \\
\hline Wednesday & 15.5 & 15.4 & 16.1 & 15.8 & 16.0 & 16.2 & 16.5 & 16.2 & $\mathbf{0 . 1}$ \\
\hline Thursday & 13.4 & 13.8 & 14.8 & 14.8 & 15.1 & 15.4 & 14.9 & 15.3 & $\mathbf{0 . 2}$ \\
\hline Friday & 3.6 & 5.3 & 10.8 & 10.5 & 13.5 & 13.6 & 13.1 & 11.7 & $\mathbf{1 . 3}$ \\
\hline Total & 100.0 & 100.0 & 100.0 & 100.0 & 100.0 & 100.0 & 100.0 & 100.0 & \\
\hline
\end{tabular}




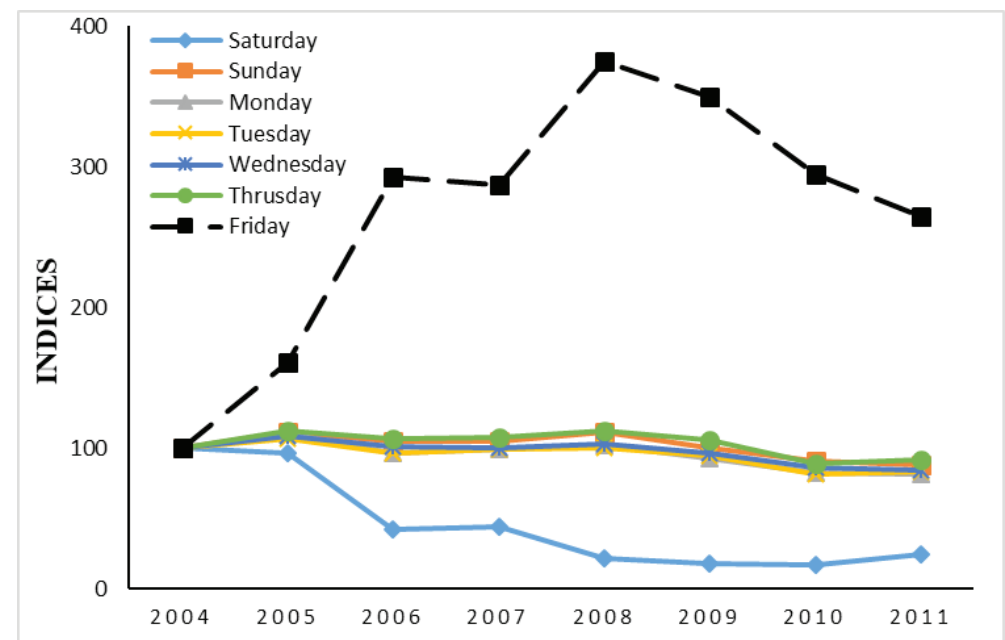

Figure 8 Trends in occupational injuries by day of the week in Saudi Arabia between 2004 and 2011

office safety policies. This increase may also challenge the traditional notion of white collar workers (administrative jobs) as safe in developing countries, but only specific further investigation will be able to provide some answers.

Similar to a report from Qatar (14), the most common cause of occupational injuries were blows, followed by falls and abrasions. However, what caught our attention the most is the increasing trend in unspecified occupational injuries, also reported by Bakhtiyari et al. for Iran (15). It may be owed to a classification system that does not bother to detail what may be important information about the epidemiological aspects of occupational injuries. Whatever the reason, this issue calls for more attention. In contrast, we observed a consistent drop in "allergic body reactions", which may point to lower exposure to allergens at work.

The increased trend in secondary contusions, cuts \& punctures, fractures \& crushes, and dislocations may be associated with the intensified use of machinery and tools in industrial and construction settings.

As for the distribution of injuries by body parts, our findings about an increasing trend in injuries of the upper extremities is in agreement with the findings in Oman (16), but not with the report by Al-Thani et al. (14) for Qatar, which singles out lower extremities as the most frequently injured body parts.

The share of injuries still under treatment has decreased in our study, which is likely owed to improved medical treatment, whereas injuries resulting in disability have been consistent.

One of the interesting findings is that most of the occupational injuries occurred on Friday and the fewest on Saturday. The reader should be aware of the cultural differences in the work week between Middle Eastern and Western countries. In Saudi Arabia, weekends start with Thursday and end with Saturday, whereas in the Western countries they start with Friday afternoons and end with Sundays. A study from the USA (20) reporting the highest rate $(37 \%)$ of occupational injuries on Sundays may therefore point to a similar social behaviour on weekends, despite cultural differences. It looks as though workers relax most and sleep the least on the central weekend days, which are from Thursday to Friday in the Middle East and from Saturday to Sunday in the West.

\section{CONCLUSION}

In conclusion, the decrease in occupational injury indices and in the $N_{i} / N_{w}$ ratios seem to point to improved safety at work and to a similar pattern with other neighbouring countries with the high share of foreign, mostly blue collar workforce. This study, however, has a number of limitations stemming from the limitations of the GOSI database, which does not distinguish age groups of insured workers, loss of working hours against occupational injuries, or medical cost due to occupational injuries. It also does not include uninsured workers. Furthermore, a number of injuries have not been specified in the database as to the type, cause, and body part affected, and the period between 2012 and 2016 has not been as specific as the rest in terms of incidence by day of the week, type of injury, and body part affected. Even so, it is the first comprehensive insight into the trends, which calls for further investigation and improvement of the database on the national level.

\section{Acknowledgments}

We wish to thank GOSI for allowing us access to its database for analysis.

\section{Conflict of interest}

None to declare. This study has been done independent of the data provider GOSI.

\section{REFERENCES}

1. Takala J, Hämäläinen P, Saarela KL, Yun LY, Manickam K, Jin TW, Heng P, Tjong C, Kheng LG, Lim S, Lin GS. Global 
estimates of the burden of injury and illness at work in 2012 J Occup Environ Hyg 2014;11:326-37. doi: 10.1080/15459624.2013.863131

2. Lebeau M, Duguay P, Boucher A. Costs of occupational injuries and diseases in Québec. J Safety Res 2014;50:89-98. doi: 10.1016/j.jsr.2014.04.002

3. Bhattacharya A. Costs of occupational musculoskeletal disorders (MSDs) in the United States. Int J Ind Ergon 2014;44:448-54. doi: 10.1016/j.ergon.2014.01.008

4. Groenewold M, Brown L, Smith E, Haring Sweeney M, Pana-Cryan R, Schnorr T. Burden of occupational morbidity from selected causes in the United States overall and by NORA industry sector, 2012: A conservative estimate. Am J Ind Med 2019;62:1117-34. doi: 10.1002/ajim. 23048

5. Jamison DT, Breman JG, Measham AR, Alleyne G, Claeson M, Evans DB, Jha P, Mills A, Musgrove P, editors. Disease Control Priorities in Developing Countries. New York (NY): Oxford University Press; 2006.

6. Murphy PL, Sorock GS, Courtney TK, Webster BS, Leamon TB. Injury and illness in the American workplace: a comparison of data sources. Am J Ind Med 1996;30:130-41. doi: 10.1002/(SICI)1097-0274(199608)30:2<130::AIDAJIM3 $>3.0 . \mathrm{CO} ; 2-4$

7. Smith GS. Public health approaches to occupational injury prevention: do they work? Inj Prev 2001;7(Suppl 1):i3-10. doi: 10.1136/ip.7.suppl_1.i3

8. Ahasan MR, Partanen T. Occupational health and safety in the least developed countries - a simple case of neglect. J Epidemiol 2001;11:74-80. doi: 10.2188/jea.11.74

9. Khasawneh A. Improving occupational health and workplace safety in Saudi Arabia. Int J Dev Sust 2014;3:261-7.

10. The Embassy of the Kingdom of Saudi Arabia. Labor and Workmen Law. Royal Decree No. M/21 dated 6 Ramadan
1389 (15 November 1969) Decision of the Council of Ministers No. 745, dated 23/24 Sha'ban1389 (3/4 November 1969) [displayed 15 May 2019]. Available at https://www. saudiembassy.net/labor-and-workmen-law

11. Abbas M, Kashif M, Balkhyour M, Ahmad I, Asam ZZ, Saeed $\mathrm{R}$. Trends in occupational injuries and diseases among Saudi and non-Saudi insured workers. East Mediterr Health J 2018;24:1010-7. doi: 10.26719/2018.24.10.1010

12. Barss P, Addley K, Grivna M, Stanculescu C, Abu-Zidan F. Occupational injury in the United Arab Emirates: epidemiology and prevention. Occup Med 2009;59:493-8. doi: 10.1093/occmed/kqp101

13. Al Haadir S, Panuwatwanich K. Critical success factors for safety program implementation among construction companies in Saudi Arabia. Procedia Eng 2011;14:148-55. doi: 10.1016/j.proeng.2011.07.017

14. Al-Thani H, El-Menyar A, Abdelrahman H, Zarour A, Consunji R, Peralta R, Asim M, El-Hennawy H, Parchani A, Latifi R. Workplace-related traumatic injuries: insights from a rapidly developing Middle Eastern country. J Environ Public Health 2014;2014:430832. doi: 10.1155/2014/430832

15. Bakhtiyari M, Delpisheh A, Riahi SM, Latifi A, Zayeri F, Salehi M, Soori H. Epidemiology of occupational accidents among Iranian insured workers. Safety Sci 2012;50:1480-4. doi: 10.1016/j.ssci.2012.01.015

16. Al-Rubaee FR, Al-Maniri A. Work related injuries in an oil field in Oman. Oman Med J 2011;26:315-8. doi: 10.5001/ omj.2011.79

17. Brogmus GE. Day of the week lost time occupational injury trends in the US by gender and industry and their implications for work scheduling. Ergonomics 2007;50:446-74. doi: $10.1080 / 00140130601133826$

\section{Epidemiologija ozljeda na radu među osiguranim radnicima u Saudijskoj Arabiji od 2004. do 2016.}

Retrospektivno smo analizirali godišnja izvješća o ozljedama na radu od 2004. do 2016., koje objavljuje državna agencija za socijalno osiguranje Kraljevine Saudijske Arabije. Za svaki smo kriterij izračunali odgovarajući indeks pomoću jednadžbe $N_{Y} / N_{r e f}$ x 100, gdje $N_{Y}$ označava broj ozljeda na radu prema specifičnom kriteriju u pojedinoj godini $Y$, a $N_{r e f}$ broj ozljeda u odgovarajućem kriteriju zabilježen u 2004., koja je uzeta kao referentna godina. Također smo izračunali omjer ozljeda i registriranih radnika $\left(N / N_{w}\right)$ za različita zanimanja i gospodarske sektore kako bismo dobili jasniju sliku trenda ozljeda po radniku. Primijetili smo porast učestalosti ozljeda na radu (u odnosu na 2004.) u građevinskom i financijskom/nekretninskom sektoru, među inženjerima i tehničarima, u broju infekcija i sekundarnih kontuzija, u broju ozljeda gornjih i donjih udova, s uzrocima koji su najviše kategorizirani kao "ostali”. Većina se ozljeda dogodila petkom, koji je dan vikenda u Saudijskoj Arabiji. Također smo primijetili veću učestalost oporavka bez invaliditeta (status ozljede). No kad se pogleda broj ozljeda na radu po radniku, primjećuje se padajući trend za sva zanimanja i sve gospodarske sektore, ponajviše, vjerujemo, zbog poboljšanja zakonskih odredbi o radu i sigurnijoj praksi kod osiguranih radnika. Naši rezultati slični su onima iz drugih zemalja Perzijskoga zaljeva te odražavaju trenutačne probleme vezane uz zdravlje i sigurnost radnika.

KLJUČNE RIJEČI: Generalna organizacija socijalnog osiguranja; građevinski radnici; infekcije; inženjeri; kontuzije; rad; tehničari; zemlje Perzijskoga zaljeva 